\title{
THE INFLUENCE OF ADVERTISING AND PERSONAL SELLING ON BUYING INTEREST
}

\author{
Adi Utama \\ Universitas Langlangbuana, Indonesia \\ Adi.utamaa@gmail.com
}

\begin{abstract}
Clothing is very popular these days. Advertising and Personal Sales are very important for companies to promote and influence people to be interested in buying products. The purpose of this study is to determine the effect of advertising on interest, to determine the effect of personal selling on buying interest, and to determine the effect of advertising and personal selling on Dr. Ricks Denim. The research method used is descriptive verification, a population of 19,500 people, with a sample of 100 respondents. The data analysis method uses multiple regression analysis and hypothesis testing. The results obtained from advertising affect buying interest in Dr. Ricks Denim. Overall respondents indicated that Dr. Ricks Denim Advertising still needs to be improved because there are still some ranks below the average such as information about product clothing models, clothing sizes according to information. Personal sales affect Dr. buying interest Ricks Denim. Overall respondents are considered quite good, this shows that Personal Selling still needs to be improved because there are still many ratings below the average. Advertising and personal selling affect Dr.'s buying interest Denim Ricks simultaneously show that Ho was rejected. Thus Personal Advertising and sales can increase consumer buying interest.
\end{abstract}

Keywords: Advertising, personal selling, buying interest

\section{INTRODUCTION}

Bandung is a city known as a city of creative industries. The clothing industry in Bandung is very closely related to factory outlets, distribution stores, and clothing companies. Distribution stores are more referring to companies that sell products that are limited in production, where they usually only resell products, without having their brand, but this company may not necessarily have its shop or produce its goods.

Marketing activities can be interpreted as human activities that take place with the market. According to Kasmir \& Jakfar (2012) marketing can also be interpreted as an effort to create and sell products to various parties with a specific purpose. The marketing mix strategy includes product strategy, pricing strategy, location or distribution strategy, and promotion strategy. The purpose of using the concept of marketing is to improve customer relations because a better relationship is very profitable for the company, and can increase profits. To be able to increase profits the company must be able to increase sales volume. According to Dharmmesta (2014), profitable sales volume must be the company's goal, and not a volume for the sake of the volume itself. To increase sales volume the company must be able to market its products properly. The company's marketing activities will greatly affect sales volume. The increase in sales volume can be achieved if the marketing mix strategy is implemented in the company appropriately. Promotion strategy is the last marketing mix activity. In facing competition, companies need promotion strategies to be able to introduce their products and attract the attention of consumers. Advertising is very important for marketing success. Advertising according to Kotler \& Keller (2016) is any form of presentation that is not done by people and in the form of promotion of ideas, goods, or services by sponsors 
that have been determined. Promotion through advertising is very effective because it can provide clear information about the product, and advertising also provides direction for consumers to choose products that are deemed appropriate to their needs. According to Alekam et al (2012), there are 3 things from advertising that can influence the purchase intention to be appointed as a dimension in this study, namely: - Creating Awareness: advertising can help consumers get a picture of the brand of a product or service advertised and known by the public (identification).

- Providing Product Information: advertisements can provide clear, useful, and trusted product information.

- Consumer Helping to determine the worth of product: advertising helps consumers to decide which products are worth buying.

Besides Advertising, Personal Selling is important for companies to promote and influence people or to be interested in making decisions about purchasing a product. According to Shimp (2015), Personal selling is a form of communication of individuals where a salesperson deals with potential buyers and tries to influence them to buy their products or services. Personal selling is an interaction between individuals, meeting each other face, which is intended to create, improve, control, or maintain a mutually beneficial exchange relationship with other parties. Communication by individuals can be more flexible compared to other promotional tools. In this way, the salesman can find out the desires, motives, and behavior of consumers at the same time can see consumer reactions about the products offered by the company. Sales Promotion can also be a short-term incentive strategy that can increase interest in buying products and direct sales at the time.

Interest is one of the psychological aspects that has a considerable influence on behavior and is also a source of motivation that will lead to what they will do. Interest is the awareness of an object, person, problem, or situation that has a relationship with him. About marketing, a consumer must have a desire for a product category before deciding to buy the product. This is what marketers mean by arousing interest in a category, which is also called an effort to create primary demand. According to Yamit (2015), Interest is an evaluation of afterpurchase or evaluation results after comparing what is felt with expectations. So buying interest is an impetus that arises in a person to buy goods and services to meet the needs.

Dr. Ricks Denim is one of the clothing brands originating from Bandung that has a tagline or motto that is High-Grade Quality which means high quality, so the products made must have the highest standard, quality ingredients so that consumers choose this brand to be one of the top choices in look, but the results of Dr. Ricks Denim management records show that denim sales are currently in decline. Providing Product Information: advertisements can provide clear, useful, and trusted product information. The purpose of this study is to determine the effect of advertising on interest, to determine the effect of personal selling on buying interest, and to determine the effect of advertising and personal selling on Dr. Ricks Denim.

\section{METHODS}

The research method used by the author is the descriptive method, while the nature of this study is verification. According to Sugiyono (2015), descriptive research is a method used to describe or analyze a research result that is used to conclude. According to Sugiyono (2015) defines the verification method as follows:

The research method through a proof is to test the hypotheses of the results of descriptive research with statistical calculations so that the results of the proofs show that the hypothesis is rejected or accepted. 
The descriptive method is used to describe or describe the problems related to the question of the independent variable that describes Personal selling, advertising, and buying interest, while verification analysis is an analysis of models and evidence that is useful for finding the truth of the proposed hypothesis. Verification research in this study is to determine the effect of advertising and personal selling on buying interest. The population studied by the author is Dr. Ricks' consumer or follower, amounting to 19,500 people. Data processing using SPSS 25 , so that the processing can be done quickly, precisely, and to produce the various outputs desired by decisionmakers.

\section{RESULTS AND DISCUSSION}

Research carried out on Dr. Ricks Denim. The purpose of this study was to determine the effect of advertising and personal selling on buying interest, in this study the questionnaire was divided into three variables, namely advertising, personal selling, and buying interest.

Responses to the Advertising Variables can be seen in the recapitulation of respondents' responses regarding advertisements which have an average value of 3.35 at intervals of $2.60-3.39$. From this analysis, it can be concluded that advertising on Dr. Ricks Denim is quite good and fulfills the elements of advertising theory.

Responses regarding personal selling, the recapitulation of respondents' responses regarding personal selling is said to be high, having a value of 3.34 at intervals of 2.60 - 3. 39 From this analysis, it can be concluded that personal selling Dr. Ricks Denim has been implemented well and fulfills the elements of personal selling theory.

Responses Regarding Purchase Interests, 3.34 at intervals $2.60-3.39$. From this analysis, it can be concluded that personal selling Dr. Ricks Denim has been implemented well and fulfills the elements of personal selling theory.

Based on the results of processing advertising data and personal selling research on buying interest, carried out in part and in conjunction with the help of the SPSS program, the reason for using SPSS is its function to assist in processing statistical data precisely and quickly and to produce the various outputs desired by decision-makers.

To find out the relationship between advertising and buying interest carried out in part and conjunction with the help of the SPSS program 25.

Table 1. Correlation test and Determination Coefficient Test of Advertising

\begin{tabular}{|c|c|c|c|}
\hline $\begin{array}{ll}\text { Model } & R\end{array}$ & R Square & $\begin{array}{l}\text { Adjusted R } \\
\text { Square }\end{array}$ & $\begin{array}{l}\text { Std. Error of the } \\
\text { Estimate }\end{array}$ \\
\hline, $779 a$ & ,606 & ,602 & 4,62255 \\
\hline
\end{tabular}

Source: The data is processed using SPSS 25 (2019)

Based on the results of the correlation calculation above, a value of rs 0.779 was obtained. This means that advertising has a strong relationship with buying interest which is in the interval $0,600-0,799$. To find out the effect of advertising on buying interest based on the value of $r$ square that is 
0.606 or $60.6 \%$, the magnitude of the effect of advertising on buying interest is $60.6 \%$ and the rest is influenced by other factors. This shows that good advertising influences buying interest.

Table 2. Hypothesis Test of Advertising

\begin{tabular}{|c|c|c|c|c|c|}
\hline \multirow[t]{2}{*}{ Model } & \multicolumn{2}{|c|}{$\begin{array}{c}\text { Unstandardized } \\
\text { Coefficients }\end{array}$} & \multirow{2}{*}{$\begin{array}{c}\text { Standardized } \\
\text { Coefficients } \\
\text { Beta }\end{array}$} & \multirow[t]{2}{*}{$\mathrm{t}$} & \multirow[t]{2}{*}{ Sig. } \\
\hline & B & Std. Error & & & \\
\hline (Constant) & 7,549 & 1,503 & & 5,024 &, 000 \\
\hline $\mathrm{X} 1$ & 875 & ,071 & ,779 & 12,283 & ,000 \\
\hline
\end{tabular}

It can be seen that $t$ arithmetic 12.283> t table 1.984 which means Ho is rejected and $\mathrm{Hi}$ is accepted. This means that advertising influences buying interest.

Table 3. Correlation test and Determination Coefficient Test of Personal Selling

\begin{tabular}{|c|c|c|c|c|}
\hline Model & $\bar{R}$ & R Square & $\begin{array}{l}\text { Adjusted R } \\
\text { Square }\end{array}$ & $\begin{array}{l}\text { Std. Error of the } \\
\text { Estimate }\end{array}$ \\
\hline 1 &, $765^{a}$ & ,585, & ,581 & 4,74512 \\
\hline
\end{tabular}

Based on the results of the correlation calculation above, a value of rs 0.765 was obtained. This means that Personal Selling has a strong relationship with buying interest which is in the interval 0,600 - 0,799. To find out the effect of Personal Selling on buying interest based on the value of $r$ square that is 0.585 or $58.5 \%$, the magnitude of the effect of Personal Selling on buying interest is $58.5 \%$ and the rest is influenced by other factors. This shows that good Personal Selling influences buying interest.

Table 4. Hypothesis Test of Personal Selling

\begin{tabular}{|c|c|c|c|c|c|c|}
\hline \multicolumn{2}{|c|}{ Model } & \multicolumn{2}{|c|}{$\begin{array}{c}\text { Unstandardized } \\
\text { Coefficients }\end{array}$} & \multirow{2}{*}{$\begin{array}{c}\text { Standardized } \\
\text { Coefficients } \\
\text { Beta }\end{array}$} & \multirow[t]{2}{*}{$\mathrm{t}$} & \multirow[t]{2}{*}{ Sig. } \\
\hline & & B & Std. Error & & & \\
\hline \multirow[t]{2}{*}{1} & (Constant) & 4,617 & 1,807 & & 2,555 & ,012 \\
\hline & $\mathrm{X} 2$ & 614 & ,052 & ,765 & 11,755 & ,000 \\
\hline
\end{tabular}

Source: The data is processed using SPSS 25 (2019) 
Based on table 4, it can be seen that $\mathrm{t}$ arithmetic 11.755> t table 1.984 which means $\mathrm{Ho}$ is rejected and $\mathrm{Hi}$ is accepted. This means that Personal Selling influences buying interest.

Table 5. Simultaneous Hypothesis Test

\begin{tabular}{lrrrrr}
\hline & $\begin{array}{c}\text { Sum of } \\
\text { Squares }\end{array}$ & df & Mean Square & F & Sig. \\
\hline 1 Regression & 3389,655 & 2 & 1694,827 & 85,263 &, $000^{\mathrm{a}}$ \\
Residual & 1928,135 & 97 & 19,878 & & \\
Total & 5317,790 & 99 & & & \\
\hline
\end{tabular}

Source: The data is processed using SPSS 25 (2019)

Based on table 5, the result obtained from the comparison of the significance level is that $\mathrm{HO}$ is rejected because $\mathrm{F}$ sig $0.00<0.05$.

Based on the results of research and discussion on the effect of Advertising and Personal Selling on Dr. Ricks Denim's buying interest are as follows. Advertising influences buying interest in Dr. Ricks Denim based on the results of hypothesis testing which shows $\mathrm{Ho}$ is rejected and $\mathrm{Ha}$ is accepted. While the responses of respondents as a whole are considered quite good, this shows that Dr. Ricks Denim Advertising still needs to be improved because there are still many ratings below the average such as information on product clothing models, clothing sizes the following information and information on material quality.

\section{CONCLUSION}

Advertising and Personal Selling affect the buying interest of Dr. Ricks Denim based on the results of simultaneous hypothesis testing which shows that $\mathrm{Ho}$ is rejected and $\mathrm{Ha}$ is accepted. Thus Advertising and Personal Selling can increase consumer buying interest. While the responses of respondents as a whole are considered quite good, this shows that Dr. Ricks Denim Advertising still needs to be improved because there are still many ratings below the average such as information on product clothing models, clothing sizes the following information and information on material quality. Meanwhile, Personal Selling on Dr. Ricks Denim still needs to be improved because there are still many ratings below the average such as the appearance of salespeople, start a conversation, communication skills, knowledge of salespeople, presentations.

\section{REFERENCES}

Alekam, Jamal Mohammed Esmail, et al. (2012). The Influence of Trust, Advertising, Family on Intention, and Actual Purchase of Local Brand in Yemen. American Journal of Economics.

Dharmmesta, Basu Swastha \& Handoko, Hani. (2014). Manajemen Pemasaran: Analisis Perilaku Konsumen. Yogyakarta: BPFE.

Kasmir \& Jakfar. (2012). Studi Kelayakan Bisnis. Cetakan ke Delapan. Jakarta: Kencana.

Kotler, Philip \& Kevin Lane Keller. (2016). Marketing Managemen, 15th Edition. Pearson Education, Inc.

Shimp, Terence A. (2015).
Komunikasi


Almana : Jurnal Manajemen dan Bisnis Vol. 4 No. 2/ Agustus 2020

ISSN 2579-4892 print/ ISSN 2655-8327 online

\section{Empat.}

Sugiyono. (2015). Metode Penelitian

Pendidikan (Pendekatan

Kuantitatif, Kualitatif dan $R \& D)$.

Bandung: CV. Alfabeta.

Yamit, Zulian. (2015). Manajemen

Kualitas Produk \& Jasa.

Yogyakarta: Ekonisia. 